MARTYNA REDER (D) orcid.org/ 0000-0002-9511-302

Poradnia Psychologiczno-Pedagogiczna w Dąbrowie Górniczej Psychological and Pedagogical Counselling Centre, Dąbrowa Górnicza e-mail: martyna.reder@gmail.com

KINGA TUCHOLSKA (D) orcid.org/ 0000-0001-9226-1328

Instytut Psychologii Stosowanej, Uniwersytet Jagielloński, Kraków Institute of Applied Psychology, Jagiellonian University, Kraków

DANUTA RODE

Uniwersytet SWPS, Wydział Zamiejscowy w Katowicach University of Social Sciences and Humanities, Faculty in Katowice

\title{
Wybrane predyktory integralności psychospołecznej w późnej dorosłości
}

\section{Chosen Predictors of Psychosocial Integrity in Late Adulthood}

\begin{abstract}
According to the Erikson's theory, personality development is associated with a positive resolution of developmental conflicts, appearing in stages, as a result of human interaction with the social and culture world. People in late adulthood are faced with the difficult task of finding a balance between the syntonic and dystonic feature of ego - integrity and despair - having a chance to develop life wisdom, deciding how to perceive themselves, other people and the surrounding world. The aim of this paper is to present and discuss predictors of psychosocial integrity in the late adulthood. Psychosocial integrity was a dependent variable, while the level of basic hope, level of depression and anxiety as a trait and selected sociodemographic data were independent variables. The study of elderly people $(\mathrm{N}=152)$ used the Measures of the Psychosocial Development (MPD) by G. Hawley (polish adaptation: Z. Uchnast), the Basic Hope Inventory (BHI-12) by J. Trzebiński and M. Zięba, the Hospital Scale of Anxiety and Depression (HADS) by A.S. Zigmond and R.P. Snaith (polish adaptation: K. de Walden-Gałuszko and M. Majkowicz) and the Sociodemographic Data Sheet, designed by the authors of the study. It has been proved that the level of psychosocial integrity depends mainly on the level of basic hope, but it is also determined by the level of education of the respondents, which is important for the perceived level of anxiety and depression.
\end{abstract}

Keywords: psychosocial integrity, basic hope, psychosocial crisis, psychosocial development, late adulthood, anxiety

Słowa kluczowe: rozwój psychospołeczny, integralność psychospołeczna, nadzieja podstawowa, depresyjność, lęk, późna dorosłość 


\section{WPROWADZENIE}

Okres starzenia się stanowi szczególny czas w życiu człowieka. W pewnym sensie jest on szczególnie trudny, ponieważ sprawność w wielu aspektach spada, osłabieniu ulegają funkcje poznawcze, sprawność fizyczna, a także jakość funkcjonowania społecznego (Bee, 2004; Straś-Romanowska, 2004; Lazarus, Lazarus, 2006; Steuden, 2014). Pojawiają się liczne problemy ze zdrowiem, które często przybierają formę chorób przewlekłych, pogarszających istotnie jakość egzystencji osób starych (Derejczyk, 2002). Człowiek, który dotychczas funkcjonował samodzielnie, staje się bardziej zależny od innych osób - potrzebuje wsparcia, a czasami również stałej asysty w wykonywaniu codziennych czynności (Wiśniewska-Roszkowska, 1989).

Etap starości może być rozpatrywany pod kątem licznych strat i narastających trudności. Nie należy jednak zapominać, że jest to także okres mądrości, w którym doświadczenia całego życia mogą kumulować się i owocować w niezwykle ważne - z punktu widzenia nadawania znaczenia własnej egzystencji - przemyślenia (Steuden, 2014). Z tego powodu naukę, która zajmuje się badaniem i opisywaniem zjawisk psychicznych związanych ze starością, Carl Jung (1993) określił mianem psychologii pełni życia.

Obserwując rosnącą średnią długości życia, James W. Vaupel (2000) zauważa, że spory odsetek ludzi żyjących współcześnie może dożyć późnego wieku, a za kilkadziesiąt lat obecność 90-latków i 100-latków nie będzie niczym nadzwyczajnym w naszym społeczeństwie. Zważywszy na coraz lepszy poziom funkcjonowania seniorów, a także dużą motywację badaczy do identyfikowania predyktorów pomyślnego starzenia się, temat przystosowania się do późnej starości wydaje się posiadać duży potencjał eksploracyjny.

Projekty badawcze, które mają na celu odkrywanie nowych faktów dotyczących starości, koncentrują się w dużej mierze na poszukiwaniu zasobów psychicznych i możliwości rozwojowych osób starszych (Straś-Romanowska, Frąckowiak, 2009). Mają więc badacze duże nadzieje na uzyskanie empirycznych dowodów na to, że zdobyta wiedza pomoże lepiej radzić sobie z ograniczeniami i znacznie poprawić funkcjonowanie tak dużej grupy społecznej, jaką są obecnie ludzie w wieku podeszłym.

Duże znaczenie dla rozumienia problematyki starości mają prace Erika Eriksona (1997, 2004), twórcy koncepcji rozwoju psychospołecznego, którego zdaniem rozwój człowieka przebiega fazowo, obejmując także finalny etap życia. Późna dorosłość to czas, kiedy konieczne jest rozwiązanie ostatniego kryzysu rozwojowego (,,integralność ego versus rozpacz"). Jednym z czynników, niewątpliwie mogącym wywierać wpływ na jakość życia w późnej dorosłości, jest poziom integralności psychospołecznej, która stała się przedmiotem zainteresowania wielu badaczy.

\section{INTEGRALNOŚĆ PSYCHOSPOLECZNA}

Integralność psychospołeczna, zdaniem E. Eriksona (2002), jest syntoniczną siłą ego, charakterystyczną dla ostatniego kryzysu rozwojowego. Ostatnie stadium rozwoju, w ujęciu E. Eriksona, jest etapem życia, w którym człowiek łączy dotychczas zebrane doświadczenia i stara się odkryć ich sens na tle całego swego życia. Starsza osoba staje wówczas przed trudnym zadaniem odnalezienia balansu pomiędzy syntoniczną a dystoniczną cechą ego - integralnością psychospołeczną a rozpaczą, w wyniku czego ma szansę rozwinąć mądrość życiową, która wpływa na sposób postrzegania siebie, innych ludzi i otaczającego świata. Mądrość, objawiająca się zdolnością do dojrzałego i refleksyjnego odnoszenia się do fundamentalnych kwestii egzystencjalnych, rozwija się dzięki zintegrowaniu dotychczasowych doświadczeń. Integralność psychospołeczna pozwala człowiekowi uchwycić znaczenie doświadczeń na wcześniejszych etapach życia.

Starość, nazywana wiekiem utrat, sprzyja dokonywaniu bilansu życiowego i poszukiwaniu elementów spajających wspomnienia. Starsi ludzie są bardziej skłonni dogłębnie analizować przeszłe wydarzenia i zastanawiać się, czy przeżyli życie tak, jak - z obecnego punktu widzenia - chcieliby i powinni. Dokonują więc podsumowań dotychczasowych osiągnięć. To, 
czy okres późnej dorosłości jest dla człowieka źródłem dumy i zadowolenia, zależy w dużej mierze od sposobu, w jaki przeżył on swoje dotychczasowe życie. Starość jest kumulacją wcześniejszych wydarzeń, których człowiek doświadczył w swojej historii (Bühler, 1999).

Cynthia M. Torges, Abigail J. Stewart i Lauren E. Duncan (2008), poszukując predyktorów integralności, zidentyfikowali cechy osób wyróżniających się pomyślnym rozwiązaniem ósmego kryzysu rozwoju psychospołecznego i dowiedli, że osiągnięcie wysokiego poziomu generatywności w wieku średnim jest predyktorem wysokiego poziomu integralności ego w późnej dorosłości. Podkreślili także istotną rolę wyzbycia się poczucia żalu (regret resolution) w kształtowaniu integralności.

Michał Bebrysz i Wanda Zagórska (2017), inspirując się E. Eriksona teorią rozwoju psychospołecznego oraz podejściem Nancy K. Leidy i Cynthii S. Darling-Fisher (1995), postanowili zidentyfikować różnice $\mathrm{w}$ obrębie profili integracji osobowej pomiędzy grupą osób zdrowych oraz pacjentów z diagnozą depresji. Wykazali, że poziom integracji osobowej u badanych z łagodną lub umiarkowaną depresją jest niższy niż u badanych nie ujawniających symptomów zaburzeń nastroju. Dowiedli także, że zasoby psychospołeczne osób będących w stanie depresji są znacznie słabiej rozwinięte, co wiąże się z trudnościami w radzeniu sobie z codziennymi wyzwaniami i rozwiązywaniem konfliktów - zarówno interpersonalnych, jak i intrapersonalnych.

Okazuje się, że nie tylko zaburzenia psychiczne, ale również somatyczne mają związek z przebiegiem rozwoju osobowości człowieka. Analizowano znaczenie stopnia integralności psychicznej dla samopoczucia pacjentów z chorobą nowotworową i dowiedziono, że stanowi ona istotny czynnik wzmacniający poczucie dobrostanu (well-being) u osób chorych terminalnie (Alon, Sela, Carmel, 2017). Osoby o niskim poziomie integralności, próbując radzić sobie z lękiem przed śmiercią, częściej stosują mechanizmy obronne; niepomyślna diagnoza skutkuje u nich przeżywaniem cierpienia psychicznego i rozpaczy. Pacjenci, których integralność ego osiąga wysoki poziom, potrafią stawić czoła trudnej sytuacji, uruchamiając zasoby pomocne
W zmaganiu się ze świadomością nieuchronnie zbliżającej się śmierci.

Podjęto również próbę określenia zależności poziomu integralności ego od warunków zamieszkania seniorów. Zbadano poziom integralności ego u osób w późnej dorosłości, które zamieszkiwały instytucje pomocy społecznej, oraz tych, które żyły w domu, wraz ze swoimi bliskimi (de Jose, 2009). Okazało się, że seniorzy mieszkający z rodziną, w porównaniu z pensjonariuszami domów opieki, charakteryzowali się znacznie wyższym poziomem integralności ego, a ponadto: niższym poziomem lęku przed śmiercią, mniejszą skłonnością do przypominania sobie przykrych wydarzeń z przeszłości, wyższym poczuciem dobrostanu i osiągnięć życiowych. Co ciekawe, wiek, stan cywilny i liczba dzieci nie miały związku z poziomem integralności ego, natomiast istotna okazała się płeć - badania wykazały, że kobiety osiągają wyższy poziom integralności ego niż mężczyźni. Znaczenie ma również poziom wykształcenia; im wyższy stopień edukacji, tym wyższy poziom integralności.

$\mathrm{W}$ podobnym badaniu, monitorującym jakość życia belgijskich seniorów, nie stwierdzono istotnych statystycznie różnic w poziomie integralności ego pomiędzy osobami zamieszkującymi domy opieki a zamieszkującymi domy rodzinne (Dezutter, Toussaint, Leijssen, 2014). U badanych sprawdzano rozkład czterech cech: umiejętności przebaczania i symptomów depresyjnych, a także integralności i rozpaczy. Analizy danych zebranych od całej grupy badanych seniorów pozwalają wnioskować, że indywidualne odnalezienie balansu pomiędzy dwiema przeciwstawnymi cechami - integralnością a rozpaczą - jest istotnym wewnątrzpsychicznym mechanizmem pomagającym $\mathrm{w}$ osiągnięciu równowagi pomiędzy umiejętnością przebaczania a uczuciami depresyjnymi, niezależnie od tego, czy żyje się w domu rodzinnym, czy też zamieszkuje instytucje opieki społecznej. Wydaje się więc, że pewne bieżące okoliczności - takie jak warunki bytowe - nie mają tak dużego wpływu na subiektywną ocenę jakości życia seniorów, ponieważ decydujące znaczenie ma efekt podsumowań, stanowiących bilans ogólny subiektywnego poczucia osiągniętych w życiu sukcesów i doznanych porażek. 


\section{NADZIEJA PODSTAWOWA}

Psychospołeczna koncepcja rozwoju, sformułowana przez E. Eriksona, nadaje kształtującej się we wczesnym dzieciństwie nadziei status fundamentalnej siły życiowej, będącej cnotą (virtue) lub kompetencją ego (ego competence). E. Erikson (1997) uznaje, iż aktywuje ono, kształtuje i podtrzymuje cały dalszy rozwój psychologiczny człowieka.

Nadzieja podstawowa formuje się w wyniku otrzymywania troski od najbliższych w pierwszych miesiącach życia - do jej ukształtowania niezbędne są akceptujące, czułe związki z innymi. Właściwą troskę może zapewnić tylko taka osoba, która ufa sama sobie i na której można polegać. E. Erikson w swoich pracach odwoływał się do definicji nadziei, zaczerpniętej ze słownika Websera, podkreślając, że ufność, w wyniku której kształtuje się nadzieja podstawowa, to „poleganie na integralności drugiego” (Erikson, 1997, s. 281). Z drugiej strony, uważał, że „cykl życia zwraca się pod koniec ku swoim początkom”, a „ostatnia faza zdaje się mieć ogromne potencjalne znaczenie dla fazy pierwszej" (Erikson, 2002, s. 77). Należy zatem zwrócić uwagę na zastosowanie koła w modelu Eriksona w sposobie ujmowania ludzkiego życia - młodzi ludzie uczą się żyć i mieć nadzieję od starszych, których integralność powinna być na tyle duża, by nie bali się pojmować życia w całej jego okazałości, a więc nierozerwalnie z procesem umierania. Wydaje się więc, że można doszukiwać się wzajemnej relacji pomiędzy integralnością psychospołeczną a nadzieją podstawową na każdym etapie życia - a w szczególności na etapie późnej dorosłości, kiedy integralność, pomagająca opanować trwogę przed przemijaniem, rozwija się najsilniej.

\section{PROBLEM BADAWCZY}

Jak wynika z E. Eriksona teorii rozwoju psychospołecznego (Erikson, 1997; 2002; 2004), warunkiem osiągnięcia sukcesu $\mathrm{w}$ rozwiązaniu ostatniego, ósmego kryzysu rozwojowego (,,integralność versus rozpacz"), jest powodzenie w rozwiązaniu poprzednich konfliktów. Celem podjętych badań jest odpowiedź na następujące pytania badawcze: Czy poziom nadziei podstawowej, pierwszej siły ego wyrosłej z konfliktu „ufność versus nieufność”, stanowi istotny predyktor poziomu integralności psychospołecznej, syntonicznej cechy ego, pojawiającej się w okresie późnej dorosłości? Czy obecność symptomów depresyjnych i lękowych oraz wybrane zmienne socjodemograficzne mają znaczący udział w determinowaniu efektu rozstrzygnięcia ostatniego kryzysu rozwoju psychospołecznego?

Sformułowano następujące hipotezy badawcze $(\mathrm{H})$ :

- H1. Wysoki poziom nadziei podstawowej jest predyktorem wysokiego poziomu integralności psychospołecznej u osób w późnej dorosłości.

- H2. Wysoki poziom depresyjności i lęku jest predyktorem niskiego poziomu integralności psychospołecznej u osób w późnej dorosłości.

- H3. Wybrane zmienne socjodemograficzne (tj. młody wiek, pozostawanie w związku, wykształcenie wyższe, aktywność zawodowa, pozytywna ocena stanu zdrowia, wysoka istotność wiary religijnej i spraw z nią związanych dla podejmowania kluczowych decyzji życiowych, poczucie przynależności i bliskości w relacjach społecznych) są predyktorami wysokiego poziomu integralności psychospołecznej u osób w późnej dorosłości.

\section{METODA}

\section{Grupa badana i procedura badań}

W badaniu wzięły udział 152 osoby w wieku od 60 do 94 lat $(M=72.73 ; S D=6.75 ; M e=73)$. Dominowali seniorzy w wieku 78 lat. Typowy badany (50\% obserwacji) był w wieku od 68 do 78 lat. Rozkład wieku $(\mathrm{K}-S=.06 ; p>.05)$ okazał się zgodny z krzywą Gaussa.

Badani tworzyli zróżnicowaną grupę, wśród której znalazły się zarówno osoby zaangażowane w aktywność w klubach seniora i na Uniwersytecie Trzeciego Wieku, jak i nieuczestniczące 
w zajęciach zorganizowanych. Na podstawie literatury (Torges, Stewart, Duncan, 2008; Dezutter, Toussaint, Leijssen, 2014) przyjęto, że w rozwoju integralności psychospołecznej największe znaczenie będzie miało subiektywne poczucie, że jest się aktywnym uczestnikiem życia społecznego - co niekoniecznie musi znajdować odzwierciedlenie w deklaracji uczęszczania na zajęcia. Nie będąc słuchaczami UTW, seniorzy realizują potrzebę przynależności poprzez różne inne działania (np. spotkania z przyjaciółmi, opiekę nad wnuczętami, uczestniczenie w kołach zainteresowań), dostosowują liczbę i formę podejmowanych aktywności do własnych preferencji.

Badanie miało charakter indywidualny. Było dobrowolne i anonimowe. Zbieranie materiału do analizy odbywało się od lutego do kwietnia 2018 roku. Zestawy metod zostały przekazane badanym osobiście, po uprzednim umówieniu się na krótkie spotkanie, a także podane do wypełnienia przez osoby znajome lub wysłane pocztą. Warunkiem podstawowym była systematycznie podejmowana aktywność intelektualna. Do udziału zaproszono seniorów, którzy w wywiadzie wstępnym wykazywali przejawy dbałości o utrzymanie sprawności poznawczej (np. regularne czytanie literatury, rozwiązywanie krzyżówek). Celem tak zaprojektowanej procedury rekrutacji było zwiększenie prawdopodobieństwa, że badani zrozumieją poprawnie treść zadawanych im pytań.

\section{Techniki badawcze}

Do pomiaru poziomu integralności psychospołecznej u badanych wykorzystano Inwentarz Rozwoju Psychospołecznego (IRP) (Hawley, 1988). Polską wersję kwestionariusza opracował Z. Uchnast w 1997 roku. IRP zawiera 112 pozycji. Wypełniając inwentarz, badani określają adekwatność każdego stwierdzenia w stosunku do ich osoby na 5-stopniowej skali Likerta (gdzie 0 oznacza ,zupełnie fałszywe”; 4 -,„zupełnie prawdziwe”) .

Inwentarz Rozwoju Psychospołecznego bada zarówno siłę ego, jak i jego słabość. Bazując na teorii rozwoju psychospołecznego E. Eriksona, w metodzie wprowadzono dwie grupy skal: 8 skal rozwoju i 8 skal regresji, które odpowiadają sile syntonicznych i dystonicznych obszarów rozwoju ego.

Każdy z ośmiu kryzysów jest reprezentowany przez twierdzenia typowe dla korzystnych i niekorzystnych zachowań w aspekcie rozwoju psychospołecznego. Obliczenie różnicy pomiędzy wynikami w skali rozwoju a wynikami w skali regresji, stosownie do rozpatrywanego etapu rozwojowego, pozwala na otrzymanie informacji dotyczącej miary wzrostu siły ego.

W przypadku określania poziomu rozwiązania kryzysu „integralność ego vs. rozpacz”, wzięto pod uwagę wynik uzyskany przez badanego w skali Integralność/Rozpacz (R8-Int/Roz).

Badania normalizacyjne potwierdziły zadowalające wartości psychometryczne Inwentarza Rozwoju Psychospołecznego (IRP). Trafność narzędzia została wielokrotnie zweryfikowania w pracach naukowych. Wskaźniki rzetelności (alfa Cronbacha) wahają się pomiędzy .65 a .84 dla skal pozytywnych i .69 a .83 dla skal negatywnych (Uchnast, 2016).

Kwestionariusz Nadziei Podstawowej (Basic Hope Inventory, BHI-12) (Trzebiński, Zięba, 2003) składa się z 12 itemów, dotyczących doświadczeń i przekonań, poprzez które wyraża się siła nadziei podstawowej. Osoba badana określa stopień zgodności twierdzenia z jej osobistym poglądem na opisywane kwestie, zaznaczając jedną z pięciu odpowiedzi na skali Likerta (od 1 - „zdecydowanie nie zgadzam się” do 5 „zdecydowanie zgadzam się”) .

Po wypełnieniu kwestionariusza badany może uzyskać wynik w przedziale od 9 do 45 punktów, który stanowi wskaźnik ogólnego poziomu nadziei podstawowej. Przyjmuje się, że im wyższy wynik badany osiąga, tym większa siła jego nadziei podstawowej.

Ustalony w badaniach, potwierdzony przez Jerzego Trzebińskiego i Mariusza Ziębę (2003), wskaźnik zgodności wewnętrznej (alfa Cronbacha) waha się pomiędzy .60 a .81. Uzyskano wysoką stabilność narzędzia. Współczynnik korelacji $r$ Pearsona w badaniu 136-osobowej grupy, przy dwukrotnym wypełnieniu kwestionariusza, wyniósł .62 (Trzebiński, Zięba, 2003).

Szpitalna Skala Lęku i Depresji (Hospital Anxiety and Depression Scale, HADS) (Zig- 
mond, Snaith, 1983) jest narzędziem służącym do badania symptomów lękowych i depresyjnych u pacjentów leczących się z powodu chorób somatycznych. Może być stosowana jako metoda przesiewowa w wykrywaniu zaburzeń lękowych i depresyjnych u osób nieidentyfikowanych jako pacjenci psychiatryczni. Jego prostota i rzetelność umożliwia stosowanie go w różnych kontekstach i u różnych pacjentów. Autorami polskiej adaptacji są Krystyna de Walden-Gałuszko i Mikołaj Majkowicz (2001).

Narzędzie to jest krótkim kwestionariuszem samoopisowym, składającym się z 14 diagnostycznych stwierdzeń, ocenianych przez badanego poprzez nadanie każdemu z nich odpowiedniej liczby punktów ( 0 punktów - brak objawów; 3 punkty - znaczne nasilenie objawów). Pozwala ustalić wynik w dwóch podskalach: HADS-A (anxiety), mierzącej natężenie lęku oraz HADS-D (depression), badającej obecność symptomów depresyjnych. Na podstawie wyniku w poszczególnych podskalach możliwe jest określenie natężenia stanów depresyjnych oraz lękowych u osoby badanej.

Badanie polską adaptacją narzędzia (Borawska-Kowalczyk, Sands, 2014) wykazało, że Szpitalna Skala Lęku i Depresji jest narzędziem rzetelnym i trafnym. Rzetelność narzędzia (alfa Cronbacha) wyniosła .83. Satysfakcjonujące okazały się również wskaźniki rzetelności dla poszczególnych podskal (HADS-A: $a=.73$; HADS-D: $a=.77)$. Wykazano dodatnią korelację między wynikami w podskali HADS-A i obiema podskalami Inwentarza Stanu i Cechy Lęku (STAI). Współczynnik korelacji rho-Spearmana pomiędzy podskalą HADS-A a podskalą lęku jako stanu (STAI X-1) wyniósł $\rho=.52$; $p<.001$, z kolei pomiędzy podskalą HADS-A a podskalą lęku jako cechy (STAI X-2) wyniósł $\rho=.71 ; p<.001$. Wykazano również dodatnią korelację pomiędzy podskalą depresji HADS-D i Skalą Depresji (CES-D) $(\rho=.49 ; p<.001)$ (Borawska-Kowalczyk, Sands, 2014).

W celu uzyskania informacji na temat zmiennych socjodemograficznych opracowano Arkusz Danych Socjodemograficznych. Arkusz ten składa się z 10 pytań, dotyczących podstawowych informacji o osobie badanej, tj. wieku, płci, miejsca zamieszkania, stanu cywilnego, wykształcenia, aktywności zawodowej, subiektywnej oceny stanu zdrowia, istotności wiary religijnej i spraw z nią związanych dla podejmowania kluczowych decyzji życiowych, subiektywnie odczuwanej bliskości w kontaktach interpersonalnych oraz ostatnio podejmowanych czynności, które wypełniały czas badanego.

Zmienne psychologiczne, będące przedmiotem badania, tj. mierzony IRP poziom integralności ego oraz mierzony BHI-12 poziom nadziei podstawowej, należą do względnie stałych charakterystyk człowieka. Nasilenie symptomów lękowych i depresyjnych, mierzone HADS, stanowi zmienną charakterystykę człowieka; zmienne te odnoszą się do stanu psychicznego.

\section{WYNIKI}

W celu poszukiwania zmiennych mających istotne znaczenie dla deklarowanego poziomu integralności psychospołecznej badanych, która została zmierzona za pomocą Inwentarza Rozwoju Psychospołecznego (IRP), przeprowadzono analizę regresji liniowej. Zmienną zależną była integralność psychospołeczna, a predyktorami - poziom nadziei podstawowej, mierzony Kwestionariuszem BHI-12, poziom depresyjności i lęku jako cechy (wynik Szpitalnej Skali Lęku i Depresji HADS) oraz zmienne socjodemograficzne, tj. wiek badanych, płeć, stan cywilny, miejsce zamieszkania, zawód, liczba kontaktów społecznych, ocena własnego zdrowia, wyznawana wiara. Predyktory, które nie wpływały istotnie na zmienną zależną w kolejnych krokach analizy, usuwano $\mathrm{z}$ modelu.

Ostatecznie utworzony model zawiera cztery predyktory i wyjaśnia ponad $49 \%$ (skorygowane $R^{2}=.493$ ) zmienności zmiennej zależnej (tabela 1)

Obejmuje on dwa predyktory o dodatniej relacji ze zmienną zależną oraz również dwa o związku ujemnym. Model okazał się dobrze dopasowany do danych $(F=37.765 ; p<.01)$ (tabela 2).

Uzyskane współczynniki regresji zamieszczono w tabeli 3. 
Tabela 1. Podsumowanie modelu

\begin{tabular}{|c|c|c|c|c|}
\hline Model & R & R-kwadrat & $\begin{array}{c}\text { Skorygowane } \\
\text { R-kwadrat }\end{array}$ & $\begin{array}{c}\text { Błąd standardo- } \\
\text { wy oszacowania }\end{array}$ \\
\hline 1 & .712 & .507 & .493 & 6.229 \\
\hline
\end{tabular}

Tabela 2. Współczynniki analizy wariancji określające poziom dopasowania modelu ( $\mathrm{df}$ - stopnie swobody, F - test Fishera, p - poziom istotności)

\begin{tabular}{|l|c|c|c|c|c|}
\hline \multicolumn{1}{|c|}{ Model } & $\begin{array}{c}\text { Suma } \\
\text { kwadratów }\end{array}$ & $\boldsymbol{d} \boldsymbol{f}$ & $\begin{array}{c}\text { Średni } \\
\text { kwadrat }\end{array}$ & $\boldsymbol{F}$ & $\boldsymbol{p}$ \\
\hline regresja & 5861.827 & 4 & 1465.457 & 37.765 & .01 \\
\hline reszta & 5704.272 & 147 & 38.805 & & \\
\hline ogółem & 11566.099 & 151 & & & \\
\hline
\end{tabular}

Tabela 3. Współczynniki regresji uzyskane w modelu. Zmienna zależna: integralność psychospołeczna (B - współczynnik niestandaryzowany, SE - błąd standardowy B, $\beta$ - współczynnik standaryzowany, $\mathrm{t}$ - wartość testu, $\mathrm{p}$ - poziom istotności)

\begin{tabular}{|l|c|c|c|c|c|}
\hline \multicolumn{1}{|c|}{ Predykatory } & B & SE & $\boldsymbol{\beta}$ & $\mathbf{t}$ & $\mathbf{p}$ \\
\hline stała & 20.031 & 6.352 & & 3.154 & .02 \\
\hline wykształcenie & 2.479 & .854 & .172 & 2.904 & .04 \\
\hline nadzieja podstawowa & 1.114 & .135 & .493 & 8.240 & .01 \\
\hline depresyjność & -.696 & .168 & -.274 & -4.150 & .01 \\
\hline lęk & -.306 & .167 & -.121 & -1.832 & .07 \\
\hline
\end{tabular}

Odczytując wyniki $(\beta)$, można dostrzec, że najsilniejszy wpływ na poziom integracji psychospołecznej wykazuje poziom nadziei podsta$(\beta=-.274)$, a także wykształcenie $(\beta=.172)$, wynik na granicy istotności statystycznej, poziom lęku $(\beta=-.121)$. Tabela 4 przedstawia chawowej $(\beta=.493)$ oraz depresyjność badanych rakterystyki rozkładu wymienionych zmiennych.

Tabela 4. Podstawowe statystyki (M - średnia, Me - mediana, Md - dominanta, SD - odchylenie standardowe) wraz z analizą rozkładu (K-S - wartość testu Kołmogorowa-Smirnowa) dla analizowanych zmiennych

\begin{tabular}{|l|c|c|c|c|}
\hline \multicolumn{1}{|c|}{ Statystyki } & Wyksztalcenie & Depresyjność & Lęk & $\begin{array}{c}\text { Nadzieja } \\
\text { podstawowa }\end{array}$ \\
\hline $\mathrm{M}$ & 3.56 & 13.27 & 14.88 & 49.14 \\
\hline $\mathrm{Me}$ & 4 & 13 & 15 & 50 \\
\hline $\mathrm{Md}$ & 4 & 10 & 14 & 50 \\
\hline $\mathrm{SD}$ & .61 & 3.44 & 3.46 & 8.75 \\
\hline Min & 1 & 7 & 7 & 28 \\
\hline Maks & 4 & 26 & 26 & 75 \\
\hline K-S & $.38^{*}$ & $.09^{*}$ & $.08^{* *}$ & $.09^{* *}$ \\
\hline
\end{tabular}

$* \mathrm{p}<.01 ; * * \mathrm{p}<.05$ 
W ostatecznym modelu nie znalazły się płeć, wiek, stan cywilny, zawód, miejsce zamieszkania, liczba społecznych kontaktów, wiara oraz podejmowane aktywności. Oznacza to, że według danych zawartych w poniższym modelu regresji wysoki poziom integralności psychospołecznej istotnie częściej występuje u osób o wysokim poziomie nadziei podstawowej, co potwierdza związki postulowane w H1. Istotna dla poziomu integralności psychospołecznej okazała się także niska depresyjność i niski poziom lęku, zgodnie z przypuszczeniami zawartymi w H2. Wybrane zmienne socjodemograficzne nie mają znaczenia dla poziomu integralności - wyjątkiem jest poziom wykształcenia. H3. nie może zatem zostać potwierdzona.

Mając na celu m.in. ujęcie szczegółowych relacji między poszczególnymi zmiennymi w modelu, postanowiono również sprawdzić jego parametry z wykorzystaniem modelowania równań strukturalnych (wykorzystano pakiet AMOS 24). Pomimo stosunkowo niewielkiej liczebności grupy badanej zadecydowano o zastosowaniu SEM do dokładniejszej analizy specyfiki relacji (siły i kierunku) pomiędzy zakładanymi predyktorami w modelu. Krok ten okazał się użyteczny w analizach danych, obrazując specyfikę oddziaływania zmiennej wykształcenie w ramach ujętych relacji, czego model regresji liniowej nie ujmował tak precyzyjnie. Model o najlepszych parametrach dopasowania do danych prezentują poniższe diagram 1 oraz diagram 2 (wynikowy).

Model okazał się interpretowalny, co przedstawia tabela 5 .

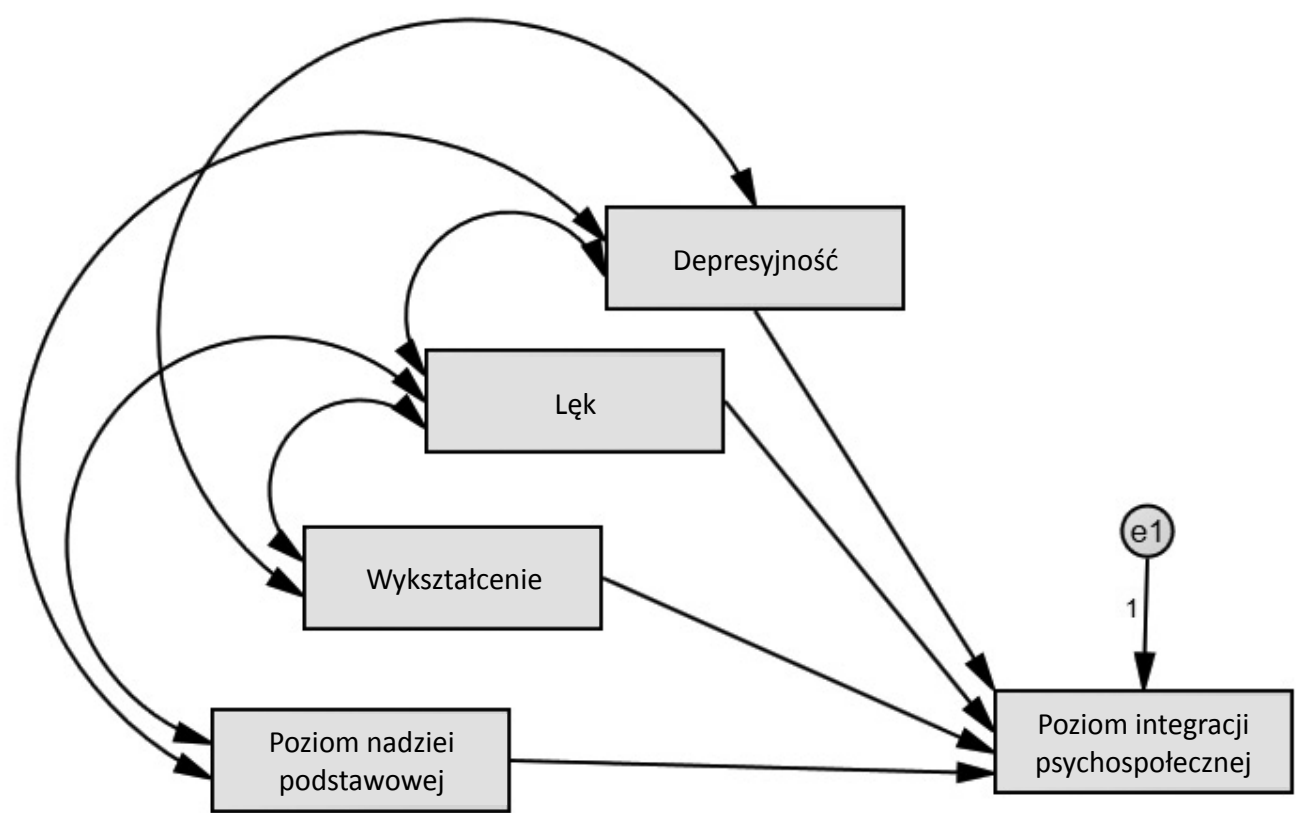

Diagram 1. Model relacji między zmiennymi dla zmiennej zależnej integracja psychospołeczna 


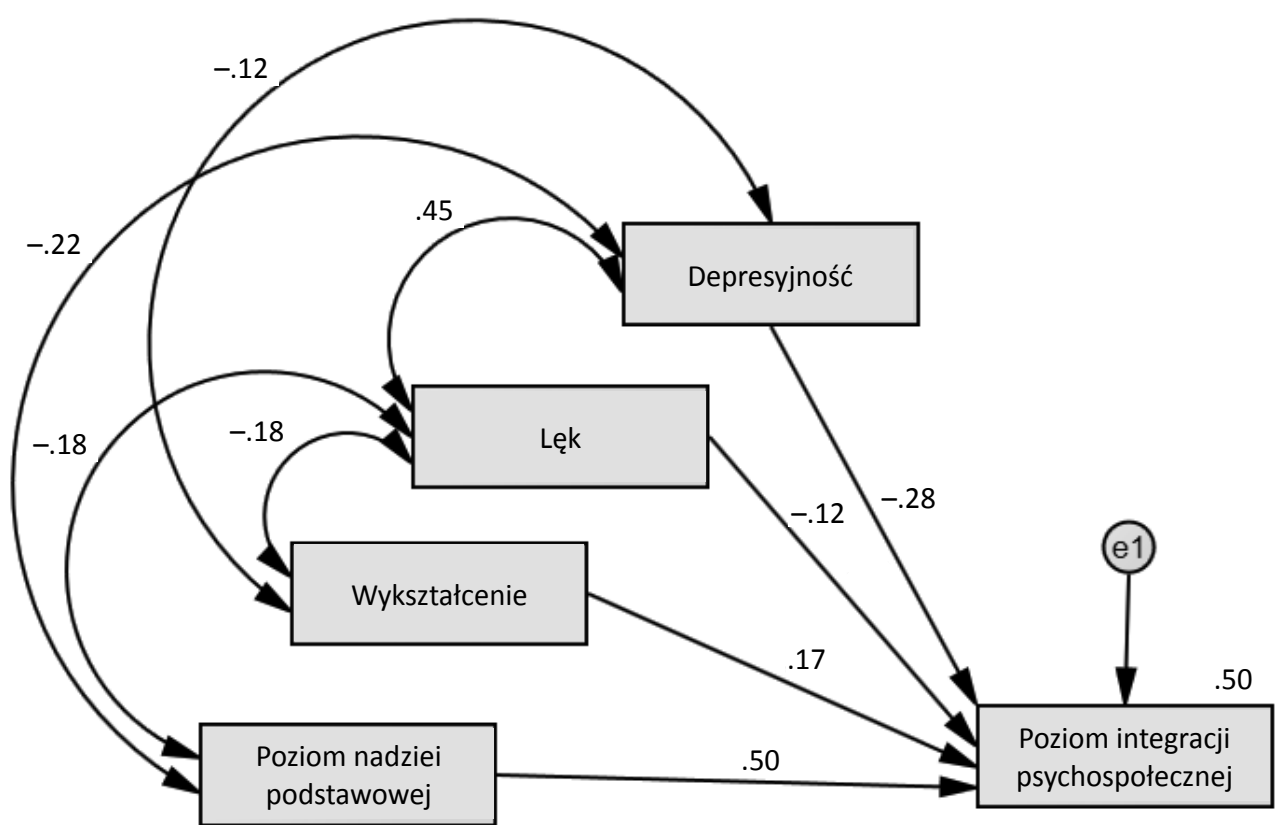

Diagram 2. Wynikowy diagram ścieżkowy dla weryfikowanego modelu

Tabela 5. Wskaźniki globalnego dopasowania modelu

\begin{tabular}{|c|c|c|c|}
\hline $\begin{array}{c}\mathrm{CHI}^{\wedge 2}(1)=.627 ; \\
\mathrm{p}=.428\end{array}$ & RMSEA $=.01$ & GFI $=.998$ & CFI $=.99$ \\
& & & \\
\hline
\end{tabular}

W ramach modelu uzyskano związki przyczynowe dla zmiennej zależnej poziom integralności psychospołecznej bardzo zbliżone do opisywanego wcześniej modelu regresji. Stwierdzono ponadto istotne wzajemne relacje pomiędzy zmiennymi: poziomem nadziei podstawowej a lękiem $(\beta=-.18)$ i depresyjnością $(\beta=-.22)$ oraz wykształceniem a tymi samymi zmiennymi $(\beta=-.18 ; \beta=-.12)$. Wykształcenie okazało się niepowiązane $\mathrm{z}$ poziomem nadziei podstawowej.

Znaczy to, iż poziom integralności psychospołecznej zależy głównie od poziomu nadziei podstawowej, ale jest także determinowany wykształceniem badanych, mającym znaczenie dla odczuwanego poziomu lęku i depresyjności.

\section{DYSKUSJA}

Celem prezentowanego badania empirycznego było zidentyfikowanie predyktorów integralności psychospołecznej u osób w wieku senioralnym. Oczekiwano, że nadzieja podstawowa będzie najsilniejszym predyktorem integralności społecznej, jako że stanowi pierwszą w ontogenezie siłę ego, która warunkuje jakość rozwoju psychospołecznego i wpływa na późniejsze osiągnięcia $\mathrm{w}$ rozwiązywaniu konfliktów w toku życia. Spodziewano się również, że istotne znaczenie $\mathrm{w}$ modelu predykcji będzie miała obecność symptomów depresyjnych i lękowych, a także wybrane zmienne socjodemograficzne. 
Wyniki potwierdziły przypuszczenia dotyczące predykcyjnego charakteru nadziei dla integralności. Nadzieja podstawowa okazała się znacząca dla kształtowania się integralności psychospołecznej w późnej dorosłości.

E. Erikson (2002) podkreśla znaczenie pierwszego stadium dla całego cyklu rozwojowego. Podczas pierwszego kryzysu człowiek ma szansę zyskać poczucie nadziei - składnik, bez którego życie w świecie społecznym byłoby pewnie niemal niemożliwe. Nadzieja kształtuje ludzkie życie na każdym etapie. Nieoceniona jest jej rola również $\mathrm{w}$ procesie godzenia się z własnym odchodzeniem, a więc u schyłku życia. Starszy człowiek staje się w dużej mierze zależny od innych - to sprawia, że konieczność zaufania innym na tym etapie staje się prawie tak istotna jak w początkowych miesiącach życia. Nie zawsze potrzeba opieki jest tak duża jak w okresie niemowlęcym, choć zdarza się, że stan zdrowia uniemożliwia samodzielną egzystencję. Wówczas starszy, schorowany człowiek staje się uzależniony od opieki i zdany na innych. Cykl życiowy zwraca się zatem pod koniec ku swoim początkom, przywracając szczególne znaczenie poczucia nadziei w późnej dorosłości. Integralność psychiczna jest więc ściśle związana z nadzieją podstawową (Erikson, 1997), co zostało dowiedzione w niniejszym badaniu. Zdaniem Zenona Uchnasta (2016), aktualne poczucie integralności własnej może być rozumiane jako wzrost nadziei podstawowej, a także posiadanie zdolności do formowania i utrzymywania wzajemności partnerskiej w relacjach międzyludzkich na każdym etapie rozwoju. Uzyskane tu wyniki badań znajdują potwierdzenie we wcześniejszych ustaleniach Z. Uchnasta.

W modelu stwierdzono także istotne relacje pomiędzy poziomem nadziei podstawowej a lękiem i depresyjnością. Wyniki te korespondują z doniesieniami innych badaczy, którzy ustalili, że większa siła nadziei występuje u osób, u których niski jest poziom lęku, depresyjności oraz tendencji samobójczych (Arnau, Rosen, Finch, Rhudy, Fortunato, 2006). Osobom zmagającym się z silnym i dojmującym stanem przedłużającego się smutku towarzyszy na ogół uczucie beznadziei, niemożności osiągnięcia satysfakcji z życia. Brak wiary w to, że życie może zyskać inny, bardziej optymistyczny przebieg sprawia, że poczucie dobrostanu obniża się, a pozytywne rozwiązanie kryzysu późnej dorosłości okazuje się utrudnione.

Uzyskane współczynniki wartości nie są tak wysokie, jak można byłoby się spodziewać, jednak ich istotność statystyczna stanowi podstawę interpretacji znaczenia dla zmiennych w relacjach. Z uwagi na niezbyt liczną, jak na próby modelowe, grupę badanych, w przyszłości zaleca się powtórzenie badania na większej próbie w celu potwierdzenia związków między zmiennymi.

W przypadku niskich wskaźników dla depresyjności i lęku można też przypuszczać, że odczuwanych przez badanych stanów obniżonego nastroju nie powinno się utożsamiać z względnie stałą dyspozycją, mającą szczególny udział w kształtowaniu integralności psychospołecznej. Interesujące mogłoby się okazać zbadanie poziomu lęku narzędziem określającym jego trwały i względnie niezmienny w biegu życia charakter. Równie ciekawe byłoby zbadanie tendencji do odczuwania nastrojów depresyjnych na przestrzeni całego życia badanego.

$\mathrm{Z}$ drugiej jednak strony, Gerben J. Westerhof, Ernst T. Bohlmeijer i Dan P. McAdams (2015) dowiedli, że integralność ego - z racji, że nie należy do stałych dyspozycji personalnych - zależy zarówno od poziomu względnie niezmiennych cech osobowości (takich jak np. ekstrawersja czy otwartość na doświadczenie), jak i cech, które podlegają fluktuacji w zależności od warunków zewnętrznych, tj. poczucia dobrostanu (well-being). Wydaje się więc, że mierzony za pomocą Szpitalnej Skali Lęku i Depresji poziom depresyjności i lęku jako stanu może dostarczać wiarygodnych i interesujących danych, które rzucają nowe światło na problematykę predyktorów pomyślnego starzenia się.

Analizując wybrane zmienne socjodemograficzne, dowiedziono, że znaczący udział w przewidywaniu poziomu integralności ma poziom wykształcenia badanych, co stoi w sprzeczności z tezą E. Eriksona (1997), który uważał, że integralność ego pojawia się naturalnie, wraz z wiekiem, niezależnie od stopnia edukacji. Wydaje się jednak, że osiągnięcie wyższego 
wykształcenia może ułatwiać rozwiązywanie dylematów późnej dorosłości, zmniejszając częstotliwość i intensywność występowania symptomów depresyjnych i lękowych. Podobną zależność - pomiędzy wyższym poziomem edukacji a wyższą integralnością ego seniorów uchwycił wcześniej w prowadzonych przez siebie badaniach Elmer G. de Jose (2009).

Warty omówienia jest fakt badania szerokiej grupy wieku, w której obrębie znalazły się zarówno osoby będące u progu starości, jak i seniorzy w późnej starości. Pomimo iż współcześni 60-latkowie są często nadal w pełni sprawni, realizując zadania średniej dorosłości, np. wspieranie dorastających dzieci i starzejących się rodziców, czy też utrzymywanie zadowalającej pozycji na rynku zawodowym (por. Havighurst, 1953), zgodnie z periodyzacją WHO zaliczani są do grupy osób starszych (Rasińska, Nowakowska, 2012). W przyszłych projektach badawczych należy przyjrzeć się wyżej opisywanej kwestii i rozważyć odrębną analizę poszczególnych grup wieku lub zastosować inne, bardziej adekwatne do współczesnych realiów społecznych kryteria definiujące późną dorosłość.

W przedstawionych badaniach własnych uchwycono zależność pomiędzy poziomem nadziei podstawowej oraz symptomów lęku i depresyjności (przejawianymi obecnie) a poziomem integralności psychospołecznej seniorów. W odnoszeniu się do modelu teoretycznego, zaproponowanego przez E. Eriksona, istotne byłoby również zbadanie wcześniejszych doświadczeń życiowych każdej z badanych osób, np. typu przywiązania, relacji rodzinnych, występowania chorób przewlekłych czy wydarzeń traumatycznych, jako tych, które mogą mieć wpływ na poziom integralności ego. Mamy nadzieję, że zapoczątkowany przez nas kierunek badań okaże się inspirujący do dalszych poszukiwań w tym obszarze.

Przedstawione w niniejszej pracy badanie stanowi empiryczną weryfikację teorii E. Eriksona, wskazując, iż cykl życia może być ujmowany w sposób kołowy. Ponieważ oba kryzysy zarówno „ufność versus nieufność”, z której rodzi się nadzieja podstawowa, jak i ,integralność ego versus rozpacz”, która owocuje pojawieniem się mądrości - mają znaczące powiązania, w cyklu życiowym niebanalne znaczenie musi mieć spotkanie różnych pokoleń, osób starszych i dzieci. Dzieci potrzebują kontaktu z seniorami, pokazującymi im świat pełen różnych odcieni, a także zaszczepiającymi w nich zalążki mądrości, uwzględniającej mnogość perspektyw i uniwersalne wartości, które pomogą rozwinąć pozostałe siły ego i cnoty w toku dalszego rozwoju psychospołecznego. Osoby starsze z kolei potrzebują kontaktu z dziećmi, by móc czerpać $\mathrm{z}$ ich ufności i umiejętności pełnego nadziei oczekiwania, niezbędnych również w dokonywaniu bilansu i podsumowań całego życia, które towarzyszą oczekiwaniu na kres. Oczekiwanie to jednak winno wiązać się z poczuciem nadziei, że życie, które niesie ze sobą cnotę mądrości, nie dobiega końca, lecz zatacza krąg, a treści przekazywane młodszym pokoleniom będą rozprzestrzeniane $\mathrm{w}$ toku rozwoju innych jednostek.

\section{BIBLIOGRAFIA}

Alon S., Sela Y., Carmel S. (2017), Effects of perception of prognosis on existential well-being and ego-integrity among advanced cancer patients. Palliative Medicine and Hospice Care, 1, 59-67.

Arnau R.C., Rosen D.H., Finch J.F., Rhudy J.L., Fortunato V.J. (2006), Longitudinal effects of hope on depression and anxiety: A latent variable analysys. Journal of Personality, 75(1), 43-64.

Bebrysz M., Zagórska W. (2017), Depresja a integracja osobowa. Ujęcie poeriksonowskie. Psychologia Rozwojowa, 22(1), 77-92.

Bee H. (2004), Psychologia rozwoju czlowieka. Poznań: Wydawnictwo Zysk i S-ka.

Borawska-Kowalczyk U., Sands D. (2014), Skala Depresji i Lęku (HADS) - zastosowanie w grupie zdrowych i chorych na mukowiscydozę nastolatków w Polsce. Pediatria Polska, 89, 27-32.

Bühler C. (1999), Bieg życia ludzkiego. Warszawa: Wydawnictwo Naukowe PWN. 
Derejczyk J. (2002), Służba zdrowia wobec potrzeb osób starszych. W: L. Frąckiewicz (red.), Polska a Europa. Procesy demograficzne u progu XXI wieku. Proces starzenia się ludności Polski i jego spoteczne konsekwencje, 125-140. Katowice: Wydawnictwo Śląsk.

Deuzutter J., Toussaint L., Leijssen M. (2014), Forgiveness, ego-integrity and depressive symptoms in community-dwelling and residential elderly adults. Journals of Gerontology. Series B: Psychological Sciences and Social Sciences, 71(5), 1-11.

Erikson E. (1997), Dzieciństwo a społeczeństwo. Poznań: Dom Wydawniczy Rebis.

Erikson E. (2002), Dopetniony cykl życia. Poznań: Dom Wydawniczy Rebis.

Erikson E. (2004), Tożsamość a cykl życia. Poznań: Zysk i S-ka.

Havighurst R. (1953), Human development and education. New York: Longmans, Green.

Hawley G.A. (1988), MPD. The Measures of Psychosocial Development. Professional Manual. Odessa: PAR Psychological Assessment Resources, Inc.

Jose E.G. de (2009), Ego-integrity of institutionalized and co-resident older adults. Hawaii International Conference on Social Sciences, June 4-7, 2009. Honolulu, USA.

Jung C.G. (1993), Wspomnienia, sny, myśli. Warszawa: Wrota.

Lazarus R.S., Lazarus B.N. (2006), Coping with Aging. Oxford: University Press.

Leidy N.K., Darling-Fisher C.S. (1995), Reliability and validity of the modified Erikson Psychosocial Stage Inventory in diverse samples. Western Journal of Nursing Research, 17(2), 168-187.

Rasińska R., Nowakowska I. (2012), Obraz ludzi starszych w raportach i zestawieniach. Nowiny Lekarskie, 81(1), 84-88.

Steuden S. (2014), Psychologia starzenia się i starości. Warszawa: Wydawnictwo Naukowe PWN.

Straś-Romanowska M. (2004), Późna dorosłość. Wiek starzenia się. W: B. Harwas-Napierała, J. Trempała (red.), Psychologia rozwoju człowieka. T. 2, 263-292. Wrocław: Wydawnictwo Uniwersytetu Wrocławskiego.

Straś-Romanowska M., Frąckowiak T. (2009), Fenomen długowieczności. Perspektywa psychologiczna. W: H. Romanowska-Łakomy (red.), Odrodzenie człowieczeństwa. Ludzkie transformacje, 383-390. Warszawa: Wydawnictwo Psychologii i Kultury ENETEIA.

Torges C.M., Stewart A.J. Duncan, L.E. (2008), Achieving ego integrity: Personality development in late midlife. Journal of Research in Personality, 42, 1004-1019.

Trzebiński J., Zięba M. (2003), Kwestionariusz Nadziei Podstawowej-BHI-12. Podręcznik. Warszawa: Pracownia Testów Psychologicznych PTP.

Uchnast Z. (2016), Integralność psychospołeczna i osobowa u seniorów oraz narzędzie do jej psychologicznego pomiaru. W: M. Kielar-Turska (red.), Starość jak ja widzi psychologia, 387-416. Kraków: WAM.

Vaupel J.W. (2000), Setting the stage: A generation of centenarians? Washington Quarterly, 23, 197-200.

de Walden-Gałuszko K., Majkowicz M. (2001), Model oceny jakości opieki paliatywnej realizowanej w warunkach stacjonarnych. Gdańsk: Zakład Medycyny Paliatywnej.

Westerhof G.J., Bohlmeijer E.T., McAdams D.P. (2015), The relation of Ego Integrity and Despair to Personality Traits and Mental Health. Journals of Gerontology: Psychological Sciences, 00, 1-9.

Wiśniewska-Roszkowska K. (1989), Starość jako zadanie. Warszawa: Instytut Wydawniczy PAX.

Zigmond A.S., Snaith R.P. (1983), The Hospital Anxiety and Depression Scale. Acta Psychiatrica Scandinavica, 67, 361-370. 